\title{
The biological half-time of hageman factor
}

Citation for published version (APA):

Veltkamp, J. J., Loeliger, E. A., \& Hemker, H. C. (1965). The biological half-time of hageman factor.

Thrombosis et diathesis haemorrhagica, 13(1), 1-7. https://doi.org/10.1055/S-0038-1656281

Document status and date:

Published: 26/03/1965

DOI:

10.1055/S-0038-1656281

Document Version:

Other version

\section{Please check the document version of this publication:}

- A submitted manuscript is the version of the article upon submission and before peer-review. There can be important differences between the submitted version and the official published version of record.

People interested in the research are advised to contact the author for the final version of the publication, or visit the DOI to the publisher's website.

- The final author version and the galley proof are versions of the publication after peer review.

- The final published version features the final layout of the paper including the volume, issue and page numbers.

Link to publication

\footnotetext{
General rights rights.

- You may freely distribute the URL identifying the publication in the public portal. please follow below link for the End User Agreement:

www.umlib.nl/taverne-license

Take down policy

If you believe that this document breaches copyright please contact us at:

repository@maastrichtuniversity.nl

providing details and we will investigate your claim.
}

Copyright and moral rights for the publications made accessible in the public portal are retained by the authors and/or other copyright owners and it is a condition of accessing publications that users recognise and abide by the legal requirements associated with these

- Users may download and print one copy of any publication from the public portal for the purpose of private study or research.

- You may not further distribute the material or use it for any profit-making activity or commercial gain

If the publication is distributed under the terms of Article $25 \mathrm{fa}$ of the Dutch Copyright Act, indicated by the "Taverne" license above, 


\section{THROMBOSIS ET DIATHESIS HAEMORRHAGICA}

EDITORES: K. M. BRINKHOUS, CHAPEL HILL; F. BÜCHNER, FREIBURG/BREISGAU; E. DEUTSCH, WIEN; J. E. JORPES, STOCKHOLM; F. KOLLER, BASEL; J. ROSKAM, LIËGE; J.-P. SOULIER, PARIS; I. S. WRIGHT, NEW YORK

\section{The Biological Half-Time of Hageman Factor}

From the Haematology Section of the Department of Internal Medicine, (Head: Prof. J. Mulder, M. D.), University Hospital, Leyden, The Netherlands

J. J. Veltkamp, E. A. Loeliger and H. C. Hemker

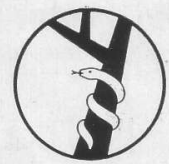


Exact data concerning the biological half-time of the Hageman factor (factor XII) have not yet been published. Hence, pertinent data found in a patient with Hageman trait after transfusion of normal plasma and in a second patient suffering from acute liver dystrophy due to phosphorus intoxication seem worth reporting.

\section{Case Reports}

Patient 1: A 63 year old unmarried woman (S. v. d. B., lab. nr. 821/60), suffering from polycythaemia vera since 1960 (pruritus, enlarged spleen, haemoglobin $19.6 \mathrm{~g} \%$, red cells 7,980,000, haematocrit $64 \%$, leucocytes 15,800 , platelet count 0.8-1.2 million), was found during bloodclotting tests before a bone biopsy to have Hageman trait. The past history gives no suggestion of congenital haemorrhagic diathesis. In spite of platelet counts of about one million, there was no increased bleeding tendency. The patient's parents are dead. Consanguinity could not be detected. Of the patients four brothers and three sisters, none of whom displays signs of haemorrhagic diathesis, five were found to have complete and the other two to have partial Hageman factor deficiency (19). The results obtained by haemostatic parameters are shown in Table 1 . Up to 1963 the polycythaemia was treated by repeated bleedings. Increasing thrombocytosis, however, warranted antimitotic therapy, which was instituted clinically. During this period a transfusion experiment was carried out. Prior examination revealed no cardiovascular pathology; X-ray of the chest disclosed signs of localized fibrosis, probably due to an old lesion of tuberculous origin, stationary since its discovery in 1950; the packed cell volume was $40 \%$, and the blood volume measured with chromium-labelled erythrocytes amounted to 5.7 litres (the patient weighed $71 \mathrm{~kg}$, the spleen was roughly 4 times normal size). Pulse rate and blood pressure were checked throughout the experiment, and $600 \mathrm{ml}$ of normal plasma (ACD excluded, ef. Methods) were given over a period of 4 hours. The patient had no fever, either after the transfusion or during the following fortnight.

Patient 2: In september 1960, a 38 year old married woman was admitted 36 hours after having attempted suicide by swallowing $500 \mathrm{mg}$ yellow phosphorus (8). Results of liver function tests indicated rapidly progressive, severe liver cell damage (Table 2). The patient's body temperature oscillated around $38^{\circ} \mathrm{C}$ throughout the period of observation.

In spite of the extremely bad prognosis, the patient was treated for her severe hepatic damage in the usual way. Vitamin $K_{1}$ was given parenterally. On the eighth day after the intake of the poison the patient died of cerebral haemorrhage. Autopsy revealed, in addition to massive fatty degeneration of the liver, cerebral, renal, mesenterial, and endocardial haemorrhages.

Thrombos. Diathes. haemorrh. (Stuttg.) 
The blood level of several of the coagulation factors, assessed daily, appeared to decrease exponentially. Half-time values are given in Table 3. The activity of factor IX and factor XII was determined in plasma samples which had been stored for $2 \frac{1}{2}$ years at $-25^{\circ} \mathrm{C}$.

Table 1. Results of Investigation of the Haemostatic Mechanism in Patient 1. Platelet Count and Thrombelastogram were Obtained on Several Occasions. The Haematocrit Value at the Time of these Investigations (1963) was $40-44 \%$.

\begin{tabular}{|c|c|c|c|}
\hline Bleeding time (Ivy) & Normal & Prothrombin consumption & Delayed \\
\hline $\begin{array}{l}\text { Capillary resistance } \\
\text { (Rumpell-Leede) }\end{array}$ & Normal & Euglobulin lysis time & 3 hours \\
\hline $\begin{array}{l}\text { Platelet count } \\
\qquad \text { (Feissly-Lüdin) }\end{array}$ & $0.8-1.2 \cdot 10^{6}$ & $\begin{array}{l}\text { Factor I (Clauss) } \\
\text { Factor II }\end{array}$ & $\begin{array}{l}350 \mathrm{mg} \% \\
95 \%\end{array}$ \\
\hline $\begin{array}{l}\text { Platelet Morphology } \\
\qquad \text { (smear) }\end{array}$ & Anisocytosis & $\begin{array}{l}\text { Factor V } \\
\text { Factor VII }\end{array}$ & $\begin{array}{l}105 \% \\
100 \%\end{array}$ \\
\hline $\begin{array}{l}\text { Recalcification time } \\
\text { (new tubes) }\end{array}$ & Strongly prolonged & Factor VIII (7) & $130 \%$ \\
\hline Thrombelastogram & $\begin{aligned} \mathrm{r}: & 31-45 \mathrm{~min} \\
& \text { (mean of } 5 \text { observ.: } \\
& 36 \mathrm{~min} \text { ) }\end{aligned}$ & Factor IX & $100 \%$ \\
\hline & $\mathrm{k}: \quad 7-10 \mathrm{~min}$ & Factor X & $120 \%$ \\
\hline & $\mathrm{ma}: 55-60 \mathrm{~mm}$ & Factor XII & $<1 \%$ \\
\hline Prothrombin time & Normal & Clot retraction & Normal \\
\hline
\end{tabular}

Table 2. Results of Investigations Reflecting Liver Damage in Patient 2, Performed on the Second Day and the Seventh Day after Admission.

\begin{tabular}{l|c|c}
\hline & Second day & Seventh day \\
\hline Bilirubin & $0.76 \mathrm{mg} \%$ & $12.8 \mathrm{mg} \%$ \\
SGOT & $136 \quad \mathrm{U}$ & $285 \mathrm{U}$ \\
SGPT & $228 \quad \mathrm{U}$ & $875 \mathrm{U}$ \\
SLDH & $340 \quad \mathrm{U}$ & $1130 \mathrm{U}$ \\
\hline
\end{tabular}

Table 3. Half -Times ( $1 / 2$ ) of Factors I, II, IX, and X Found in Patient 2 (First Column) as Compared to those Found under Normal Metabolic Conditions (Second column). The Increase of the Metabolic Decay of the Four Coagulation Factors in the Patient as Measured by their Respective Half -Times Averages 2.1 Times Normal.

\begin{tabular}{l|c|c|c}
\hline & $\begin{array}{c}\text { Patient's t 1/2 } \\
\text { (hrs.) }\end{array}$ & $\begin{array}{c}\text { Normal t 1/2 } \\
(\text { hrs. })\end{array}$ & Ratio t 1/2 $\frac{\text { Normal }}{\text { Patient }}$ \\
\hline Factor I & $54(8)$ & $122(6),(9)$ & 2.26 \\
Factor II & $29(8)$ & $72(1),(3),(15)$ & 2.48 \\
Factor X & $21.6(8)$ & $40(2),(3)$ & 1.85 \\
Factor IX & 13.2 & $24(14)$ & 1.82 \\
\hline & & & Average: 2.1 \\
\hline
\end{tabular}




\section{Materials and Methods}

Blood was collected by means of carefully done venepuncture in the antecubital veins, and handled in siliconized glassware or in plastic tubes. Normal plasma to be transfused was prepared from blood freshly drawn through plastic tubes into siliconized bottles $(470 \mathrm{ml}$ blood and $60 \mathrm{ml}$ ACD) from two blood-bank donors who displayed normal factor XII activity (about 100\% of normal).

Thrombelastographic measurements were done in plastic cuvettes (12).

The activity of factor XII was measured in a one-stage assay system (principle of the partial thromboplastin time) as described earlier for factor IX (11). The recalcification clotting times were automatically read by the coagulometer of Schnitger (18).

Statistical evaluation of the results was kindly performed by Dr. E. F. Drion, head of the department Bewerking Waarnemingsuitkomsten T. N. O., J. P. Coenstraat 22, Den Haag.

\section{Results}

The coagulation time (thrombelastographic r-value) of the blood of patient 1 showed considerable reduction after transfusion of $600 \mathrm{ml}$ fresh normal plasma. During the first two days after transfusion, $r$-values as short as $17 \mathrm{~min}$ (i.e. in the normal range) were observed. The corrective effect diminished

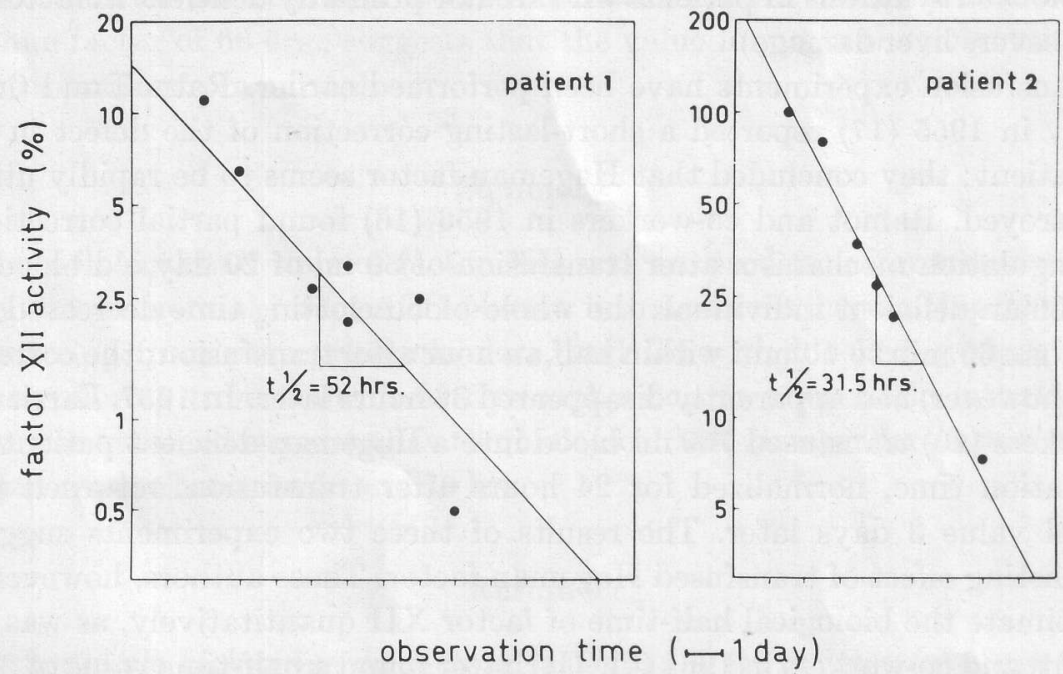

Fig. 1. Biological half-time of factor XII as calculated from activities found on successive days in a patient with Hageman deficiency (patient 1) and another patient suffering from acute liver-dystrophy (patient 2). The first-day-values were obtained 48 hours after transfusion and on the day of admission, respectively. For calculation of the factor XII activities in patient 2 a reference curve was used, in which the first-day clotting time value arbitrarily was chosen as the point representing $100 \%$. 
slowly, and could be demonstrated until the 15 th day after transfusion. As shown in Fig. 1, the biological half-times of factor XII as measured in the two patients, appeared to be 52 and $31 \frac{1}{2} \mathrm{hrs}$. respectively. The $95 \%$ confidence intervals calculated according to Student are $32-143 \mathrm{hrs}$. and $24-41 \frac{1}{2} \mathrm{hrs}$., respectively.

The half-time found in patient $2\left(31 \frac{1}{2} \mathrm{hrs}\right.$.) was considered to be about half the normal value because the metabolic decay of four other coagulation factors assessed in parallel displayed an increase of 2.1 on the average (Table 3 ). Hence, the biological half-time in this patient, under normal metabolic conditions would most probably have been considerably longer (13). Correction by the factor 2.1 (a figure which cannot be statistically defined as it is obtained from ill-defined values) results in $66 \mathrm{hrs}$. The corresponding $95 \%$ confidence interval would certainly be larger than $501 / 2^{-87}$ [which is 2.1 times $\left(24-41 \frac{1}{2}\right)$ ] due to the error introduced by the multiplicand.

\section{Discussion}

The biological half-time of factor XII may be assessed after transfusion of normal plasma into congenitally factor XII-deficient individuals as well as after blocked synthesis in patients who are not primarily deficient in factor XII (acute severe liver damage).

Transfusion experiments have been performed earlier. Ratnoff and Colopy already in 1955 (17) reported a short-lasting correction of the defect in their first patient; they concluded that Hageman factor seems to be rapidly utilized or destroyed. Ramot and co-workers in 1956 (16) found partial correction of the coagulation mechanism after transfusion of $50 \mathrm{ml}$ of 20 day old blood into a Hageman-deficient individual: the whole-blood clotting time decreased from more than $60 \mathrm{~min}$ to $10 \mathrm{~min}$ within half an hour after transfusion; the corrective effect, however, had apparently disappeared 36 hours later. In 1957, Larrieu and co-workers (10) transfused $700 \mathrm{ml}$ blood into a Hageman-deficient patient. The coagulation time, normalized for 24 hours after transfusion, returned to its original value 3 days later. The results of these two experiments suggest a short-lasting effect of transfused Hageman factor. These authors, however, did not estimate the biological half-time of factor XII quantitatively, as was done by Fantl and co-workers in 1961 (4). The latter found a half-time value of 2 days in a Hageman-deficient patient suffering from Ehlers-Danlos syndrome, who underwent extracorporeal circulation for open-heart surgery. These authors, however, disregarded a possible increase of the metabolic decay after surgical treatment (13). This neglect implies that the biological half-time might be longer than 2 days. 
In the transfusion experiment described in this paper, the biological halftime of factor XII was found to be $52 \mathrm{hrs}$, as calculated from values between the third and eleventh day after transfusion of $600 \mathrm{ml}$ freshly prepared, intact, normal ACD-plasma (Fig.1) into a factor XII-deficient recepient. The large $95 \%$ confidence interval (32-143 hrs.) is due to the widely scattered points about the regression line (see Fig.1). From the amount of Hageman factor transfused (600 $\mathrm{ml}$ of normal plasma displaying about $100 \%$ Hageman factor activity) and from the volume into which this amount is transfused [at least 4 litres (5)], it can be calculated that the top-level of Hageman factor activity attained immediately after transfusion can hardly exceed $15 \%$ if uniform distribution over intra- and extravascular space is assumed. Hence, a regression line intercepting at $15 \%$ (Fig. 1) suggests too short a half-time.

Whether the post-transfusional half-time found in patient 1 represents the normal biological half-time of factor XII cannot be decided as long as we have no exact information on (a) the disappearance rate of other coagulation factors in polycythaemia vera; and (b) the state of activation of transfused Hageman factor (a possible bias caused by gradual alteration of the state of activity of the transfused Hageman factor in vivo could not be excluded because the kaolin clotting time assay method was not ready for use at the time of the experiment).

The result of our second observation (patient 2), a biological half-time of Hageman factor of $66 \mathrm{hrs}$., suggests that the value found in the polycythaemic patient is not far from normal.

\section{Summary}

The biological half-time of factor XII was assessed (a) after transfusion of freshly-drawn, normal intact ACD-plasma into a patient having Hageman trait and suffering from polycythaemia vera, and (b) with blocked synthesis in a patient suffering from acute liver dystrophy due to phosphoric intoxication. The results obtained suggest that the biological half-time under normal conditions has a value between 50 and 70 hrs.

\section{Résumé}

La demie-vie biologique du facteur Hageman a été estimée (a) après transfusion de plasma normal et intact chez une malade souffrant d' "Hagemantrait " et atteinte de polycythémie vraie, (b) après arrêt de la synthèse du facteur XII chez une malade ayant une dystrophie hépatique aiguë (intoxication au phosphore). Dans des conditions normales, une demie-vie de l'ordre de 50-70 hrs. semble la plus probable. 


\section{Zusammenfassung}

Die biologische Halbwertszeit des Faktor XII wurde bestimmt (a) nach Transfusion von intaktem Frischplasma bei einer Patientin mit Polycythaemia vera und Hageman-Faktor-Mangel, und (b) nach Stillstand der Hageman-Faktor-Synthese bei einer Patientin mit akuter Leberdystrophie (Phosphorintoxikation). Eine Zeit zwischen 50 und 70 Std. erscheint für den Normalwert am wahrscheinlichsten.

\section{References}

(1) Borchgrevink, C. F., O. Egeberg, J. G. Pool, T. Skulason, H. Stormorken, B. Waaler: A study of a case of congenital hypoprothrombinaemia. Brit. J. Haemat. 5: 294 (1959).

(2) Caen, J., S. Yanotti, J. Varangot, J. Bernard: Étude d'un cas d'hypoproconvertinémie vraie congénitale. Sang 30: 535 (1959).

(3) Esch, B. van der: Coagulation studies in patients receiving excessively large amounts of vitamin $\mathrm{K}$ antagonists. Thesis, Leiden 1966.

(4) Fantl, P.: Repair of cardaic defect in a patient with Ehlers-Danlos syndrome and deficiency of Hageman Factor. Brit. med. J. I: 1202 (1961).

(5) Goolden, A. W. G., J. M. Gartside, L. Szur: Changes in interstitial fluid in polycythaemia vera. Clin. Sci. 23: 441 (1962).

(6) Hammond, J. D. S., D. Veret: Observations on the distribution and biological halflife of human fibrinogen. Brit. J. Haemat. 5: 431 (1959).

(7) Hardisty, R. M., J. C. Macpherson: A one-stage factor VIII (antihaemophilic globulin) assay and its use on venous and capillary plasma. Thrombos. Diathes. haemorrh. (Stuttg.) 7: 215 (1962).

(8) Hensen, A., E. A. Loeliger: Antithrombin III, its metabolism and its function in blood coagulation. Thrombos. Diathes. haemorrh. (Stuttg.) Suppl. 10 (1963).

(9) Ingram, G. I. C., J. L. Pinniger, L. Vallet: Survival in a afibrinogenaemic subject of fibrinogen prepared from "time-expired" blood. Lancet $I$ : 135 (1960).

(10) Larrieu, M. J., J. P. Soulier, Y. Culot: Déficit en facteur Hageman. Sang 28: 152 (1957).

(11) Loetiger, E. A., A. Hensen: Substitution therapy in haemophilia B. Thrombos. Diathes. haemorrh. (Stuttg.) 6: 391 (1961).

(12) Loeliger, E. A., J. J. Veltkamp, M. J. Mattern, H. J. Hooij: Disposable plastic cuvettes for thrombelastography. Thrombos. Diathes. haemorrh. (Stuttg.) 9: 519 (1963).

(13) Loeliger, E. A., B. van der Esch, H. C. Hemker, M. J. Mattern: The biological disappearance rate of prothrombin, factor VII, IX, and X from plasma in hypothyroidism, hyperthyroidism, and during fever. Thrombos. Diathes. haemorrh. (Stuttg.) 10: 267 (1964).

(14) Loeliger, E. A., A. Hensen, J.J. Veltkamp, J. van der Meer, H. C. Hemker: On the metabolism of factor IX. Internat. Symp. on Haemophilia, Washington 1963. The University of N. Carolina Press, Chapel Hill, U.S.A., 1964.

(15) Loeliger, E. A., M. J. Mattern, H. C. Hemker: Transfusion of coumarin induced hypoprothrombinaemic plasma into a patient suffering from severe congenital hypoprothrombinaemia. Thrombos. Diathes. haemorrh. (Stuttg.) In preparation.

(16) Ramot, B., K. Singer, P. Heller, H. J. Zimmerman: Hageman factor (HF) deficiency. Blood 11: 745 (1956). 
(17) Ratnoff, O. D., J. E. Colopy: A familial haemorrhagic trait associated with a deficiency of a clot promoting fraction of plasma. J. clin. Invest. 34: 602 (1955).

(18) Schnitger, H.: Entwicklung eines neuartigen Gerätes zur automatischen Registrierung von Blutgerinnungszeiten und kritischer Beitrag zur Theorie anderer Meßprinzipien für gerinnungsphysiologische Untersuchungen. Thesis, Marburg 1956.

(19) Veltkamp, J.J.: The detection of the carrier state in hereditary coagulation disorders. Thesis, Leiden 1966.

Received for publication 24.6.1964

Copyright by F. K. Schattauer-Verlag, Stuttgart - Der Verlag behält sich alle Rechte, besonders die des Nachdruckes, der Vervielfältigung und der Ubersetzung vor. 